\title{
A SUCESSÃO DO CÔNJUGE NAS CODIFICAÇÕES CIVIS BRASILEIRAS
}

\section{Leonora Roizen Albek Oliven ${ }^{1}$}

\section{RESUMO}

A pesquisa sistematiza e compara a sucessão hereditária de cônjuges na vigência das duas codificações civis brasileira. A análise é feita a partir da relevância da família matrimonializada para o direito e para a sociedade brasileira, propondo um percurso históricojurídico para a compreensão da sua importância e preocupação específica da codificação contemporânea. Compreender a posição jurídica do cônjuge de herdeiro facultativo para a de herdeiro necessário concorrente demanda a análise da estrutura das novas famílias no Brasil. A pesquisa bibliográfica e documentos legislativos embasam a comparação das normativas e a elaboração de um modelo de análise entre os sistemas sucessórios.

PALAVRAS-CHAVE: sucessões; cônjuge; concorrência; legítima; codificações.

\section{THE SPOUSE'S SUCCESSION IN BRAZILIAN CIVIL CODIFICATIONS}

\begin{abstract}
This paper systematizes and compares the hereditary succession of spouses under the two Brazilian civil codes. The analysis is based on the relevance of the matrimonial family to the law and to Brazilian society, proposing a historical-legal path to understand of contemporary coding. Understanding the legal position of the spouse of an optional heir to that of a necessary competing heir requires an analysis of the structure of new families in Brazil. The bibliographic search will allow the comparison of the norms and the elaboration of a comparative table between the systems of succession for each one of them.
\end{abstract}

KEYWORDS: successions; spouse; competition; legitimate; encodings

\section{Introdução}

Nascimento e morte transcendem a condição de fatos jurídicos naturais dos quais não é possível fugir. Eles constituem peça-chave para caracterizar a personalidade humana e todas as demais conjecturas capazes tão somente de perpetuar as lembranças dos (des)afetos, os dramas, o nome e os bens familiares. O Direito das Sucessões é o ambiente do direito civil de organização dessa transmissão patrimonial para depois da morte de uma pessoa.

\footnotetext{
${ }^{1}$ Leonora Roizen Albek Oliven, Doutora em Direito, Programa de Pós-Graduação em Direito da Universidade Veiga de Almeida, mestre em Psicanálise, Saúde e Sociedade pela Universidade Veiga de Almeida. Advogada, palestrante, pesquisadora líder do grupo de pesquisa Famílias Plurais. Professora efetiva na UVA e no IBMEC e professora convidada da pós-graduação da PUC-RIO. Endereço eletrônico leonora.oliven@gmail .com e para acessar o lattes http://lattes.cnpq.br/1070351326253691
} 
A presença do Estado na organização das famílias é revelada na forte regulação dessas relações privadas, interferindo na autonomia da vontade ao combinar a sucessão testamentária com a legítima. A partir de um afeto presumidor, o legislador reafirma a importância dos laços familiares e indica precisamente quem são pessoas que merecem e precisam de maior proteção econômica, dando continuidade às relações jurídicas patrimoniais, não atribuindo liberdade absoluta para testar, limitada pela reserva legal da família nuclear.

A concepção desse trabalho, que investiga a sucessão do cônjuge, advém da mudança de posição jurídica conquistada a partir da nova codificação. Ela inovou a posição jurídica de viúvas e viúvos, que migram de herdeiros facultativos para herdeiros necessários e concorrentes, recebendo parcela da herança de forma concomitante aos descendentes e ascendentes do autor da herança. Ainda que mantido como o terceiro na ordem da vocação hereditária, essa posição reservatária garante um lugar de vantagem na sucessão hereditária, valorizando as relações íntimas, afetivas, de apoio e amparo no desenvolvimento da vida em comum.

A pesquisa confrontará as duas grandes codificações brasileiras, através de análise histórico-jurídica, no que se refere especificamente à sucessão mortis causa, deixando o autor da herança um cônjuge sobrevivente.

A metodologia aplicada de pesquisa bibliográfica implica a análise de textos normativos e de decisões judiciais que revelam a posição da jurisprudência, dos Tribunais, possibilitando conhecer os diferentes modelos eleitos nas codificações brasileiras para a sucessão hereditária de cônjuges e pesquisa da doutrina referência. Ela será descritiva e analítica, comparando as duas codificações brasileiras em seus diferentes ritmos e proposições.

A partir da decisão de 10 de maio de 2017 do Supremo Tribunal Federal (STF), que reconheceu a inconstitucionalidade nas diferenças de regime sucessório entre cônjuge e companheiro, devem-se estender as regras sucessórias, aplicando de forma idêntica por inexistir de hierarquia entre as entidades familiares. Ao ampliar as garantias às famílias plurais, modulam-se os efeitos para que os aspectos formulados nessa pesquisa se apliquem aos dois institutos, com as diferenças e observações que revelam os espaços até aqui percorridos.

\section{A família matrimonial}


Na declaração de direitos da Constituição republicana de 1891, só é reconhecido o casamento civil como forma de instituição de família. A mesma constituição que anunciava a liberdade de crenças e cultos vedava o casamento religioso, e por mais que pareça um paradoxo, a opção integra a passagem do Estado confessional para o laico, secularizando institutos. O novo regime se anuncia leigo e deixa de atribuir efeitos jurídicos aos atos religiosos, mesmo reconhecendo a sua força estruturante daquela sociedade: "o Estado garante direitos, a Igreja determina crenças" (BARBOSA, 1872, p.92).

Até então, era instituto misto. Se de um lado era imprescindível para a atribuição de efeitos jurídicos, de outro lado só seria celebrado entre católicos. Não havia como atribuir efeitos civis próprios das famílias para as demais pessoas A regra, advinda das Ordenações Afonsinas, mantida nas Filipinas, e do direito canônico, foi assumida pelo Bispado da Bahia (AZEVEDO, 2019) e pela Constituição do Império, de 1824. Ela impulsionou uma população marginal, sem direitos civis específicos das famílias. A religião diversa à católica inviabilizava o matrimônio ou a reorganização familiar pela vontade do casal, considerando a indissolubilidade do instituto por ato inter vivos.

Na segunda metade do século XIX, o movimento migratório europeu para o Brasil exigiu uma resposta para a formalização das famílias acatólicas. Em 1861, o decreto n ${ }^{\circ} 1.144$, de 11 de setembro, complementado pelo regulamento $\mathrm{n}^{\mathrm{o}} 3.069$, de 17 de abril de 1863 , dispensa os impedimentos religiosos e estende os efeitos civis do casamento aos que professem religião diversa daquela oficial do Império - a católica - e os demais assentos e registros civis, então realizados no Livro do Vigário, típico da Igreja. Ao autorizar o casamento de brasileiros e de estrangeiros de todas as crenças, inclusive os matrimônios anteriores à publicação da lei, ela atribuiu efeitos civis com a apresentação das certidões dos celebrantes, regularizando a situação civil das famílias.

O deslocamento de poder e de dinheiro com as celebrações com a perda do monopólio fez com que a Igreja reagisse, atuando politicamente na revogação das normas. Em 1865, novamente retorna o casamento religioso como única possibilidade de organização familiar.

Em 1890, com a República, o casamento torna-se definitivamente civil, livre da Igreja e da imposição de crenças religiosas, seguindo a ideia de que "o casamento é um direito civil e tem efeitos civis: estabeleça-se o casamento do estado, o casamento civil" (BARBOSA, 1874). 
O Decreto- Lei n 181 de 24 de janeiro de 1890 é o documento que seculariza o casamento e coloca o divórcio como instrumento jurídico à disposição da separação de corpos das pessoas casadas. Ele possibilita a separação do casal e a vida em residências diferentes, sem, no entanto, permitir a dissolução do vínculo matrimonial. Era um aparelho que de alguma forma atribuía juricidade à separação, mas o casamento permanecia hígido, pois ainda indissolúvel por ato entre vivos. Ainda assim, havia uma escolha pelo casamento religioso e muitos sequer celebravam o civil, rompendo com o pretendido princípio de tolerância do Estado. Como resposta, foi editado o Decreto $\mathrm{n}^{\circ}$ 521, de 26 de junho de 1890, dispondo sobre a preferência do casamento civil antes do religioso e cominando pena de multa e prisão ao celebrante que invertesse a ordem legal.

No processo de codificação, iniciado em 1855 com a Consolidação das leis civis, seguida do Esboço do projeto de Código Civil, Teixeira de Freitas já enfrentara o debate sobre a imperatividade do casamento e a impossibilidade do divórcio como instrumento de dissolução do vínculo conjugal. Era necessário manter a ordem familiar, o estado das coisas que garantisse a identificação da origem dos filhos, a manutenção do poder do pai, o estado de submissão e de sujeição das mulheres, assegurando a continuidade da família patriarcal.

O Brasil Império, assim como o Colônia, idealizava o amor entre o divino e o profano (FURTADO, 2003). O amor propagado pela Igreja, divino e perfeito, se dava a partir do casamento. A família matrimonial organizava os deveres conjugais, sexuais e de fidelidade, fundantes da legitimidade e do nome dos filhos, assegurando o patrimônio e a certeza do destino da herança. A opção pela monogamia nas sociedades ocidentais possivelmente tem como fundamento exatamente a certeza da transmissão de bens patrimoniais pelo direito sucessório. Nela resguarda-se com uma certeza jamais absoluta a origem da filiação, da formação da família merecedora do recebimento dos bens amealhados e transmitis pelas gerações.

O casamento é organizador do sistema de alianças e de trocas, fortalece acordos econômicos e políticos. As escolhas são feitas a partir das necessidades e possibilidades de cada grande família, pensando na utilidade das alianças. É o casamento da razão, necessário para afirmar as posições políticas e jurídicas dos homens, e também as sociais e jurídicas das mulheres. $\mathrm{O}$ amor profano, sensual, não é objeto de reflexão, pois o casamento abstraía a ideia de amor romântico. O casamento adviria então da necessidade da família, não dos nubentes. $O$ 
interesse é social, de formação e fixação de reciprocidades, tornando-o não apenas modo de formação, mas produto derivado das famílias (LÉVI-STRAUSS, 1956).

É nesse ambiente que é elaborada a primeira codificação civil, de 1916. Ela é tardia, estava prevista desde a Constituição de 1824 e é representante típica da sociedade do fim do século XIX, patrimonial e patriarcal, que tem na força obrigatória dos contratos e na supremacia do direito de propriedade os grandes vetores, que mitiga os direitos das mulheres para uma posição de servilismo ao homem, sem a ingerência sobre a sua vida, os seus bens e destino. Trata-se de um código que ainda aborda as crianças como objeto do direito, com prerrogativa paterna sobre os filhos. O tempo e as reivindicações de direitos humanos darão consistência à teoria da proteção integral da criança e do adolescente, deslocando a garantia ao interesse da criança, sujeito de direito e do direito.

Até então, o casamento era a única forma de instituição da família legalizada e de pertinência da identidade civil dos filhos, indissolúvel pela vontade e assim permanecerá até o último quadrante do século XX. O impedimento às demais organizações informais de pertença em direitos tipicamente familiares, garantidores do direito ao nome e do estado filial, à sucessão hereditária, persistirá até que outros organismos familiares enfrentem a sociedade e o legislativo conservador para mudar o estado das coisas, rompendo com os privilégios de uma minoria inserida nas normas de direito das famílias e das sucessões para lutar pelos mesmos direitos civis para outras organizações familiares.

Essas famílias compostas sem a chancela estatal do casamento existiam e eram chamadas de informais, quando não de concubinárias. O reconhecimento desses arranjos como famílias é acelerado nos anos de 1960. A demanda feminista pela liberdade sexual, pelo direito ao corpo, e por amplitude nos direitos civis é revelado no Brasil e força a edição do Estatuto da Mulher Casada, de 1962. Ele não atribui os mesmos direitos às mulheres que os homens gozavam, ainda assim reduz a posição de vantagem masculina, liberando a mulher da tutela conjugal para o trabalho remunerado extradomicílio e sistematizando um regime de bens próprios a garantir a manutenção dos bens havidos pelo fruto exclusivo desse trabalho.

Os filhos nascidos fora do casamento eram discriminados. Bastardos, estavam fora da ordem familiar. Os filhos legítimos eram aqueles nascidos sob a proteção da família legítima, a matrimonializada, ou os legitimados pelo casamento superveniente dos pais. A flexibilização decorrente da lei n 883 de 21 de outubro de 1949, dispondo "sôbre o reconhecimento de filhos ilegítimos", admitiu que nos casos de dissolução da sociedade 
conjugal pelo desquite, ainda não havia divórcio capaz de extinguir o marital, e a título social, o filho reconhecido receberia por quinhão hereditário a metade do que o filho legítimo receberia. O que separava os filhos? O preconceito na legitimação, decorrente apenas do casamento dos pais, e o alijamento de todos os demais direitos civis, os mantendo inferiores aos filhos legítimos.

A lei admitirá a perfilhação de filhos de pessoas casadas através de testamento cerrado, modalidade de disposição de bens e de manifestação da vontade que demanda auto de aprovação para dar publicidade da existência de um testamento, mas não do seu conteúdo, que é ignorado. Essa forma de reconhecimento filial supostamente impediria que qualquer pessoa tomasse ciência daquela relação considerada espúria, mantendo o segredo social.

A luta pelo divórcio cada vez mais se fortalece no Brasil e, em 1977, será possível a dissolução do vínculo conjugal pela manifestação da vontade e a reorganização jurídica das novas famílias. Ainda assim há preferência pela família matrimonial e como mote para a aprovação do divórcio havia o argumento de que ele permitiria que as mulheres saíssem do concubinato e regularizassem o estado civil (CARNEIRO, 1977). Essa suposta necessidade de proteção das mulheres era a resistência de um congresso majoritariamente masculino, legislando em prol de seus interesses de manutenção do status quo garantidor da posição de vantagem.

Com regras rígidas à obtenção do divórcio, como se a sua definitividade fosse sempre colocada à prova, a lei impunha a separação como um caminho para se chegar ao destino final, um teste temporal para a reflexão. Esses requisitos e prazos mantinham as pessoas casadas por mais tempo do que o pretendido por elas. Essa era a posição do Estado, que reduzirá de três e cinco anos ${ }^{2}$ para dois ${ }^{3}$ ou um ano ${ }^{4}$ o prazo de separação para a obtenção do divórcio em 1988. A Emenda Constitucional n 66/2010 autorizou o divórcio potestativo sem prazos ou requisitos para a concessão, sendo necessária apenas a manifestação da vontade de ao menos um dos cônjuges em dissolver o vínculo.

A lei de 1977 modifica o direito hereditário dos filhos nascidos fora do casamento, igualando os quinhões sucessórios, bem como a exclusão por indignidade e por deserdação. Ela reconhece a posição de herdeiros necessários e admite o reconhecimento voluntário da filiação, desde que regularizada a separação dos pais.

\footnotetext{
${ }^{2}$ Prazos fixados originariamente pela EC 9/1977, Emenda do Divórcio.

${ }^{3}$ Divórcio direito.

${ }^{4}$ Divórcio por conversão.
} 
Esse foi um movimento de longa duração e abriu espaço para que as famílias informais se impusessem socialmente e buscassem direitos civis e familiares. Ele foi determinante em fortalecer a perspectiva de que o casamento não é a forma única de vivência dos afetos, que o rigor do Estado baliza, mas que o Direito tem maneiras de reconhecer as demais expressões de sentimentos. A transformação em opção da formalização ou não do vínculo conjugal se consolida com a Constituição Federal de 1988 (CF/88).

Partindo da premissa que as famílias se realizam na união e no afeto responsável, de desenvolvimento e de expansão da personalidade de cada um dos integrantes, tornando cada vez mais íntimas e contributiva as uniões, a Constituição não delimita fórmulas para reconhecer as famílias. As análises são realizadas a partir das mais diferentes e possíveis realizações humanas e elas revelam as suas aspirações pessoais de felicidade, é uma famíliainstrumento (DIAS, 2016).

O cenário de lutas pela liberdade e igualdade jurídica para as famílias, as mulheres em outros papeis nas relações íntimas e profissionais, as crianças e adolescentes ocupando posição de sujeito de direitos, impulsionam o processo de personalização das relações jurídicas do Código Civil de 2002, iniciado a partir da tramitação do Projeto de Lei n ${ }^{\circ} 634$, de 1975, ao final sancionado como Lei $n^{\circ} 10.406$, de 2002.

O direito de família apresentado pela nova codificação absorve, ainda que parcialmente, as orientações constitucionais. Na pluralidade das entidades familiares, reconhece as demais possibilidades de configurações e mesmo que de forma incompleta, fortalece as premissas de igualdade, de compartilhamento de responsabilidades e de afetividade nas relações familiares.

O livro das famílias inicia com o casamento estabelecendo a comunhão plena de vida e a igualdade jurídica entre cônjuges, reservando 59 artigos ao assunto, e apenas 4 artigos para as famílias advindas da união estável. Que aquela é formal e precisa da regulamentação exatamente pela sua natureza não se discute, mas o texto revela a importância e prevalência da família matrimonizalizada na obtenção de resultados e de direitos de família. A omissão aos casais homossexuais, a mitigação de direitos sucessórios para os companheiros, com tratamento diferenciado em relação aos cônjuges, são questões que precisaram ser judicializadas, deslocadas para o circuito dos tribunais.

O direito civil foi compelido a atender não apenas as demandas sociais, mas as jurídicas que se impunham a partir de tantas mudanças nas relações pessoais e patrimoniais das 
famílias, e também no direito das sucessões, indissociável e capaz de produzir efeitos não apenas de transmissão de patrimônio, mas também de outras consequências jurídicas.

\section{A sucessão legítima.}

Aberta a sucessão com a morte de uma pessoa, por força do Direito de Saisine desde logo a herança é transmitida aos herdeiros legítimos e testamentários, mantendo íntegro o princípio de que não há direitos subjetivos sem titular e garantindo cuidados na administração da herança. A Saisine impede que o patrimônio fique acéfalo, sem administração, o que poderia implicar na sua desvalorização ou perecimento. Demonstra também a coexistência, presente nas duas codificações brasileiras, da sucessão legítima com a testamentária.

A primeira decorre de uma ordem preferencial legal, e a segunda advém da manifestação da vontade expressada por testamento válido, seja para a disposição de bens ou para a informação e a organização de outros temas da vontade privada do falecido. A sucessão testamentária encontra como limite a liberdade em testar, submetida a regras de ordem pública garantidoras de um determinado quinhão da herança aos herdeiros necessários, a legítima.

Acredita-se que sucessão legítima seja subsidiária à testamentária (RIZZARDO, 2019), pois será aplicada nos casos em não há testamento válido ou o falecido não dispôs da totalidade dos bens permitidos. Nesses casos, tem um caráter supletivo, partilhando esse quinhão de acordo com as determinações dispostas em lei e não na vontade do falecido, que poderia ter interferido nessa partilha e não o fez por inércia, por vontade de seguir a ordem legal, por exclusão de sucessores ou por algum vício no documento, pois "quando o testamento colidir com a sucessão legítima, esta prevalece e não mais a autonomia da vontade do testador. As normas legais da sucessão legítima não podem ser contrariadas pela vontade do testador, salvo quando expressamente facultar-lhe o poder de escolha" (LÔBO, 2019, p.78).

A sucessão legítima revela a vontade presumida do falecido (CARVALHO, 2019, p. 336), dispondo expressamente a lei sobre a garantia de determinados quinhões hereditários a certos herdeiros, membros da grande família, extensa. Ao garantir que certos herdeiros recebam a herança do falecido, a sucessão legítima apresenta os seus personagens, os herdeiros legítimos, e os divide em duas grandes classes: os herdeiros legítimos necessários, 
também chamados de legitimários ou reservatários, e os herdeiros legítimos facultativos. Todos eles integram, ainda que presumidamente, o ambiente de desenvolvimento de vida e de personalidade do autor da herança, e a escolha adviria de "certo interesse do Estado em manter um vínculo de união entre os parentes, o que se consegue também com a permanência do patrimônio no respectivo grupo, alcançando-se uma certa garantia econômica para o futuro dos familiares do morto" (RIZZARDO, 2019, p.135).

Os herdeiros legítimos facultativos são os colaterais em até o quarto grau de parentesco do autor da herança. No Código Civil de 1916, o parentesco se estendia até o sexto grau de colateralidade, o que foi modificado pela codificação de 2002, que entendeu excessivo permitir que esses parentes tão distantes venham a recolher a herança, exceto se advier de uma deixa testamentária, revelando a intenção expressa do proprietário na transmissão patrimonial. Eles podem ser afastados da sucessão, de forma que o recebimento da herança é uma liberalidade, não há obrigatoriedade. Para isso, basta que o autor da herança teste para terceiros, o que afastaria da sucessão, sem que seja necessário declinar qualquer causa. Para que que os colaterais recebam, pode o autor da herança optar por deixar a herança seguir a regra legislativa, ou escolher alguns colaterais e afastar outros. É o ponto alto da liberdade em testar, que pode coexistir com a sucessão legítima.

O outro grupo é chamado de herdeiro legítimo necessário. Ele é especial e os seus integrantes, em regra, não podem ser afastados da sucessão, exceto nas hipóteses de exclusão de herdeiros por indignidade ou deserdação, aonde o cometimento de determinados atos especificados em lei são considerados vis, justificando o afastamento dos herdeiros dessa sucessão, desde que seja comprovada a prática. Os herdeiros necessários não são obrigados a aceitar a herança, podem renunciar aos seus quinhões, mas nesse caso trata-se de um ato abdicativo de direito originado do herdeiro, não do hereditando ou da moral social.

Por serem familiares do falecido, eles tornam-se sucessores por direito próprio, por pertencerem diretamente ao chamamento sucessório. Não há ninguém se interpondo entre o herdeiro e o falecido. Também é possível que ocorra o direito de representação. Nesse caso, o herdeiro originário não sucederá por ser pré-morto ao autor da herança. Não é possível a titularidade de direitos subjetivos por quem não tem personalidade jurídica, chamando a lei os descendentes do herdeiro primário para receber a herança em seu lugar. A estirpe receberá esse quinhão hereditário. $\mathrm{O}$ direito de representação se dá na linha descendente, jamais na 
ascendente, e como exceção é possível a representação de filhos de irmãos quando concorrerem com os demais irmãos, seus tios.

É a mesma situação a ser aplicada na indignidade e na deserdação. Os excluídos da sucessão são excepcionalmente considerados pré-mortos, em similitude jurídica de morte civil, "admitida no mundo ocidental até o século XVIII. A pessoa condenada com a morte civil perdia todos os direitos civis e políticos, cessando as relações de família e abrindo-se sua sucessão, como se estivesse morto" (LÔBO, 2019, p. 193). Para não expandir os efeitos da sanção civil de exclusão, e mantendo a intranscendência da pena, os descendentes do excluídos sucedem como se ele tivesse falecido. Não se pune os herdeiros do herdeiro excluído, somente aquele que deu causa à exclusão, fortalecendo a ideia de proteção patrimonial para a família.

O modo de suceder por transmissão também é típico da sucessão legítima, permitindo que o sucessor do herdeiro falecido antes de declarar a sua aceitação na herança o faça, ocupando o lugar do originário.

Os herdeiros legítimos necessários pertencem a uma categoria especial, são as pessoas mais próximas do falecido. Elas compõem a família nuclear de origem, de constituição, e por isso é garantida uma reserva legal de pelo menos metade da herança. Essa porção é chamada de parte legítima e é calculada com base nos bens havidos na data da abertura da sucessão, já descontadas as dívidas e as despesas do funeral, e acrescendo os bens sujeitos a colação.

$\mathrm{O}$ autor da herança não tem plena liberdade em relação aos seus bens, o que pode ser uma interferência excessiva do estado na autonomia privada, pois só o dono da coisa poderia efetivamente decidir se um determinado parente deve ou não receber bens em decorrência de sua liberalidade. Dessa forma, a sucessão legítima não pode ser confundida com liberalidade, ela é imposta ao autor da herança que obrigatoriamente deixará uma parcela significativa de seus bens àqueles a quem o Estado pretende a proteção.

Há uma ordem preferencial e excludente para essa convocação hereditária, que pode perfeitamente coexistir com a sucessão testamentária, desde que não atinja ou ultrapasse os eventuais limites impostos pela sucessão legítima à reserva legal de metade da herança aos herdeiros necessários, se houver. Essa ordem considera, à similitude do direito romano, "os laços afetivos e as relações familiares que aproximam os designados com o hereditando, quais sejam, as relações de parentesco, de casamento e de união estável” (LÔBO, 2019, p.81). Ela é orientada pelo fundamento do direito sucessório de "continuidade da família por meio da 
propriedade pela sua transmissibilidade post mortem" (AZEVEDO, 2019, p. 17), tratando da ininterrupção patrimonial a partir de um afeto presumido. Nela, certas classes precedem a outras, sendo o chamado sucessivo e excludente.

Partindo da premissa de que a família nuclear é a afetiva e merece especial proteção, ambas as codificações civis atribuíram aos descendentes e aos ascendentes posição jurídica diferenciada, sendo os primeiros vocacionados a recolher determinada herança.

Na sucessão por descendentes, o Brasil assume a igualdade hereditária a partir da Constituição Federal de 1988. Antes, a legitimidade ou ilegitimidade dos filhos refletiam na (im)possibilidade de quinhão hereditário e o século XX vai ajustando paulatinamente essas distorções. $\mathrm{O}$ direito de primogenitura não foi aplicado no Brasil, mesmo tendo o filho mais velho o dever de administrar os bens familiais, mantendo a integridade e unidade do patrimônio familiar (LÔBO, 2019).

Em relação aos ascendentes, até então a sucessão dividia-se por duas linhas - a materna e a paterna - o direito hereditário. Acredita-se necessário abrir espaço para as possibilidades de sucessões nas quais os ascendentes ocupam posição jurídica semelhante, duas mães ou dois pais, e ainda assim efetivar a partilha por linhas. Da mesma forma, no que se refere à multiparentalidade, considerando o tema 622 objeto de análise pelo STF em setembro de 2016, acredita-se que a partilha por linha ascendentes deve ser realizada pelo número de genitores que o autor da herança deixou, dividindo-se por cabeça, e não exatamente por linhas como até então a partilha era efetivada.

Para dar continuidade ao tema com a análise da sucessão hereditária dos cônjuges na vigência das duas codificações, a pesquisa assume como premissa que na vigência do Código Civil de 2002 o companheiro é herdeiro necessário e ocupa exatamente a mesma posição jurídica que o cônjuge sobrevivente, recolhendo o quinhão com base no art. 1.829 do Código Civil. A identidade jurídica se dá a partir de 2017, com a decisão proferida no tema 809 pelo STF, nos recursos RE 878694 / MG e RE 646.721/RS e o seu alcance na interpretação da codificação civil, afastando qualquer hierarquia nos regimes sucessórios para cônjuges e companheiros, independentemente da orientação sexual.

\section{A sucessão do cônjuge nas codificações brasileiras.}


Na vigência do Código Civil de 1916, o cônjuge era o terceiro vocacionado na ordem da vocação hereditária e na qualidade de herdeiro facultativo, recolhendo a herança antes dos colaterais, mas podendo ser afastado da sucessão caso o cônjuge assim o dispusesse em testamento. Ele mantinha a mesma ordem da vocação introduzida pelo Decreto $\mathrm{n}^{\circ} 1.839$, de 31 de dezembro de 1907, regulando "o deferimento da herança no caso da successão ab intestato", que alterou a disposição vigente desde as Ordenações Afonsinas 5 na qual o cônjuge sobrevivente é o quarto vocacionado, recolhendo a herança do defunto após o colateral em décimo grau (Livro IV, título 95, I). A lei de 1907 atribui a sucessão legítima tão somente ao colateral até o segundo grau, o que será modificado em 1945, com o Decreto-Lei no 8.207, fixando a sucessão no terceiro grau, com outra alteração em 1946, ampliando para o quarto grau de colateralidade, como ainda hoje.

Sob o argumento de que o regime legal supletivo do casamento era o da comunhão universal de bens, e o era durante o período colonial, no imperial e em boa parte do republicano, o cônjuge sobrevivente seria meeiro, ao menos em tese, da totalidade do patrimônio. Sendo meeiro, supostamente teria direito a metade de todo o patrimônio como direito próprio decorrente do regime de bens e estaria protegido. Esse era o argumento pela qual afastava-se o cônjuge do direito sucessório, “de tal maneira que cada cônjuge era meeiro, não havendo razão alguma para ser herdeiro. Tendo já a metade do patrimônio, ficava excluída a idéia de herança" (REALE).

A opção deixava de considerar aspectos importantes de exceções cabíveis nos regimes de bens e partia da premissa de que todas as pessoas eram casadas pelo regime da comunhão universal de bens. A assertiva não necessariamente correspondia, pois já havia os demais regimes de bens que poderiam viger por imposição legal, caso do regime da separação obrigatória de bens, ou através da manifestação da vontade diversa e formalizada no pacto antenupcial, caso dos regimes da comunhão parcial de bens e da separação convencional de bens.

O risco de que os descendentes ou os ascendentes porventura deixassem esse cônjuge sobrevivente ao desabrigo implicou na criação e dois institutos: o direito real de habitação e o usufruto vidual. Esse instituto, inserido na legislação pelo Estatuto da Mulher casada em 1962, atribuía ao cônjuge viúvo o usufruto de parte da herança do falecido enquanto durasse a viuvez e desde que não fosse casado pelo regime da comunhão universal, caso em que teria

\footnotetext{
${ }^{5}$ Fac-simile disponível em http://www.ci.uc.pt/ihti/proj/afonsinas/14p351.htm Acesso 14 abr. 2020.
} 
direito à meação. Se não houvesse a meação por força de regime de bens, o cônjuge supérstite poderia usufruir com vitaliciedade da quarta parte dos bens do cônjuge falecido, se houvesse filhos, ainda que não comuns. Se os herdeiros do falecido fossem os ascendentes, o quinhão de usufruto corresponderia à metade da herança. A mesma lei atribuiu ao viúvo casado sob o regime da comunhão universal, enquanto vivesse e mantivesse a condição de viúvo, ainda que sucedesse, o direito real de habilitação sobre o imóvel destinado à residência da família, desde que aquele fosse o único bem daquela natureza a inventariar.

Em 1977, com a Lei do Divórcio, torna-se supletório o regime da comunhão parcial de bens, modificando o sistema e capaz de tornar ainda mais delicada a não sucessão do cônjuge. Ele será meeiro nos bens havidos na constância da sociedade conjugal, como regra, mas afastado dos bens havidos por outras causas e os anteriores, permanecendo afastado do direito hereditário. O cônjuge receberia a meação, caso o regime de bens do casamento assim o dispusesse, mas não receberia quinhão hereditário.

A lei do divórcio também altera a lei no 883/1949 para dispor sobre a parcela de bens sucessíveis para o cônjuge casado pelo regime da separação de bens no caso dele suceder com filho do falecido havido fora da sociedade conjugal, hipótese de concorrência hereditária na primeira codificação.

Para que o cônjuge sobrevivente pudesse ter o direito hereditário como herdeiro facultativo, até o ano de 1977 eles não poderiam ser desquitados. Com a extinção do instituto do desquite, que é substituído pela separação judicial a partir da lei do divórcio, ele deveria conviver com o falecido à época da abertura da sucessão, exigindo-se a atualidade da relação conjugal.

Não haveria qualquer direito sucessório aos companheiros, que sequer eram reconhecidos nessa condição antes da Constituição Federal de 1988. A primeira norma a tratar de direitos sucessórios para os companheiros é a Lei n 8971/1994, que também instituiu o usufruto vidual e o direito a alimentos para os conviventes. Admitirá a partilha de bens havidos onerosamente na constância da convivência em similitude fática e jurídica a do enunciado da súmula n 380 do STF. A partir da Lei nº 9278/1996, também serão direitos dos companheiros o real de habitação e o ingresso no regime jurídico de regime de bens.

De 1996 até o início de vigência do Código Civil de 2002, cônjuges e companheiros tiveram os mesmos direitos hereditários sem qualquer posição de vantagem de uma estrutura familiar sobre a outra, garantindo a igualdade jurídica necessária à sua realização. 
A segunda codificação modificará esse modelo de igualdade para a união estável, retirando direitos dos companheiros, desvio que demandou a atuação do STF em 2017 para declarara a inexistência de hierarquia familiar após amplas discussões doutrinárias e jurisprudenciais.

No que se refere à sucessão do cônjuge no Código de 2002, foram significativas as mudanças no direito sucessório. Se antes da codificação anterior o cônjuge fora preterido aos colaterais e tornara-se herdeiro facultativo, o Código Reale, apoiado em valores éticos e sociais, inscreve o cônjuge no rol de herdeiro necessário.

A família não se estruturava mais em consanguinidade, apenas. Reconhecida a afetividade como fundante da família e o estado de companheirismo conjugal no ambiente cotidiano, acredita-se não apenas que o viúvo ficaria desamparado, mas que não seria reconhecida a sua força e atuação na economia familiar, mesmo sem contribuir financeiramente. A ideia de existência conjunta do casal deu origem á posição de concorrente ao cônjuge, para receber de forma concomitante com os descendentes e com os ascendentes como herdeiro necessário.

A nova posição jurídica atribuindo a dupla vocação é dependente do regime de bens. Para que o cônjuge sobrevivente possa concorrer com os descendentes, ele deverá ser casado pelo regime da comunhão parcial de bens, participação final nos aquestos, e no regime da separação convencional de bens, quando concorrerá tão somente nos bens particulares do autor da herança, entendimento majoritário da jurisprudência ${ }^{67}$ contemporânea.

Nos debates do projeto do Código Civil ${ }^{8}$, argumentou-se que as modificações adviriam principalmente como "consequência de alteração na estrutura do regime de bens entre os cônjuges" e das escolhas dos regimes diversos, razão pela qual seria conveniente "alargar a participação da herança do cônjuge sobrevivo".

\footnotetext{
${ }^{6}$ Nesse sentido: Enunciado 270 da III Jornada de Direito Civil realizada pelo Conselho de Justiça federal, CJF O art. 1.829, inc. I, só assegura ao cônjuge sobrevivente o direito de concorrência com os descendentes do autor da herança quando casados no regime da separação convencional de bens ou, se casados nos regimes da comunhão parcial ou participação final nos aqüestos, o falecido possuísse bens particulares, hipóteses em que a concorrência se restringe a tais bens, devendo os bens comuns (meação) ser partilhados exclusivamente entre os descendentes.

${ }^{7}$ Nesse sentido, REsp 1368123 (2012/0103103-3 - 08/06/2015) Foi voto vencido o da Min. Nancy Adrigui, que se posiciona há anos de forma diversa, entendendo que o "cônjuge sobrevivente, a par de seu direito à meação, concorre na herança apenas quanto aos bens comuns, haja ou não bens particulares, partilháveis, estes, unicamente entre os descendentes". Disponível em https://ww2.stj.jus.br Acesso em 12 abr. 2020.

${ }^{8}$ Consolidação dos debates parlamentares sobre o Código Civil Brasileiro, Audiências públicas e relatórios (1975-1983). Relatório Parcial: Parte Especial, Livro V, Do Direito das Sucessões, e Livro Complementar, Disposições Finais e Transitórias Deputado Raimundo Diniz / Celso Barros.
} 
Os casados pelos regimes da comunhão universal de bens não herdarão, seguindo a mesma ideia do Código Civil de 1916, de que o direito hereditário não seria necessário em caso de meação da totalidade de bens, ou ainda para os casados pelo regime da separação obrigatória de bens, pois a transmissão hereditária frustraria a dicção legal de incomunicabilidade de bens.

No que se refere ao regime da comunhão universal, esse argumento pode ser falacioso, especialmente quando "é possível que nesse regime haja bens particulares. A incomunicabilidade pode advir da manifestação da vontade de terceiros estranhos e alheios ao casal [...] ou da vontade dos próprios cônjuges" (OLIVEN, 2017, p. 129). Se a proteção pretendida permite a sucessão nos bens particulares, impedir o direito hereditário das pessoas casadas pelo regime da comunhão universal de bens parece desviar-se do conceito proposto nessas hipóteses em específico.

Na concorrência com os ascendentes, o viúvo concorrerá com eles independentemente do regime de bens, ampliando as possibilidades de recebimento de quinhão hereditário e em uma posição jurídica mais igualitária, considerando as frações atribuídas serem mais equânimes.

A concorrência sucessória do viúvo, aumentando a proteção, coligada ao direito real de habitação, implicou na revogação do instituto do usufruto vidual. Ele é extirpado do ordenamento. O viúvo passa a concorrer em propriedade e aparentemente não mais precisaria desse suporte patrimonial, fazendo jus ao direito real de habitação. Ele garante ao sobrevivente ${ }^{910}$, qualquer que seja o seu regime de bens, a possibilidade de permanecer gratuitamente habitando no imóvel onde havia a residência familiar, desde que seja o único daquela espécie a inventariar. Versa a garantia à moradia nas mesmas condições anteriores de resguardar a dignidade na viuvez, não submetendo a pessoa a desmandos dos demais herdeiros, o que decorre da solidariedade familiar (LÔBO, 2018), desde que o falecido seja o proprietário do bem imóvel objeto do direito. Ele se destina exclusivamente para a própria

\footnotetext{
${ }^{9}$ Para o companheiro, a doutrina e jurisprudência compreendem pela extensão do comando do art. 1831 do Código Civil, consoante enunciado $\mathrm{n}^{\circ} 117$ da I Jornada de Direito Civil, realizada pelo Conselho de Justiça Federal.

${ }^{10}$ Ainda em relação ao companheiro, a premissa número 8, publicada na ferramenta Jurisprudência em Teses do STJ, que trata da união estável, na Edição n. 50, de 2016, enuncia: "o companheiro sobrevivente tem direito real de habitação sobre o imóvel no qual convivia com o falecido, ainda que silente o art. 1.831 do atual Código Civil".
} 
moradia do viúvo e eventual abdicação ao direito real de habitação não implica em renúncia à herança, pois não é quota parte, mesmo sendo direito decorrente da sucessão.

O Código Civil de 2002 alimenta a ideia de culpa nas separações familiares em modelo semelhante ao de 1916 no que se refere ao direito hereditário. Na primeira codificação, o casal não poderia estar desquitado, separado e deveria conviver ao tempo da abertura da sucessão. Na codificação vigente, exige-se a atualidade, o que é razoável, pois a separação e fato é causa de término da sociedade conjugal, ainda que não a dissolva, mas pune o cônjuge culpado pela separação com a perda do quinhão hereditário. A culpa adviria da quebra de deveres decorrentes do casamento ou da união estável, se o caso.

A culpa não é determinante para admitir a separação ou o divórcio, ela é inoponível, em especial após a EC 66/2010, não havendo sentido em discuti-la nas hipóteses previstas originariamente, tampouco após a abertura da sucessão, quando seria oneroso aos herdeiros a prova de uma culpa póstuma.

Para além dessas dificuldades e objeções, pondera-se que não há culpa unilateral a contribuir para fim de uma relação afetiva. A conjugalidade não depende somente de uma pessoa - e o desgaste relacional é conjunto. Ainda que apenas um dos integrantes do casal tenha agido contrariando os ditames legais, as ações decorrem desse esgarçamento nos afetos, e ele é comum ao casal, a responsabilidade é conjunta.

O quadro elaborado especialmente para esse trabalho compara nas duas codificações os sistemas sucessórios dos cônjuges, e nesse ambiente inclui-se os companheiros no que se refere aos direitos no Código Civil ora vigente a partir da decisão do STF, que tem efeito vinculante, e atribui idênticos direitos para o direito hereditário, com a aplicação do art. 1829 do Código Civil, reconhecendo a inconstitucionalidade do art. 1790 do Código Civil.

\begin{tabular}{|c|c|}
\hline Código Civil de 1916 & Código Civil de 2002 \\
\hline Herdeiro facultativo & Herdeiro necessário \\
\hline Não concorrente & Concorrente \\
\hline $\begin{array}{c}\text { Terceiro vocacionado na ordem da } \\
\text { vocação hereditária }\end{array}$ & $\begin{array}{c}\text { Terceiro vocacionado na ordem da vocação } \\
\text { hereditária }\end{array}$ \\
\hline Usufruto vidual & $\begin{array}{c}\text { Extinção do instituto por haver concorrência e } \\
\text { sucessão em propriedade }\end{array}$ \\
\hline Direito real de habitação & Direito real de habitação \\
\hline
\end{tabular}

Rev. Brasileira de História do Direito | e-ISSN: 2526-009X | Evento Virtual | v. 6 | n. 1 | p. 40-60 | Jan/Jun. 2020 


\begin{tabular}{|c|c|}
\hline $\begin{array}{l}\text { Administração dos bens se casados pelo } \\
\text { pelos regimes de comunhão }\end{array}$ & $\begin{array}{l}\text { Administração dos bens se com o outro } \\
\text { convivia ao tempo da abertura da sucessão }\end{array}$ \\
\hline $\begin{array}{c}\text { Se o sobrevivente for a mulher, para herdar } \\
\text { deveria ser convivente à data de abertura } \\
\text { da sucessão }\end{array}$ & $\begin{array}{c}\text { Não deve estar separado há mais de dois anos, } \\
\text { salvo se sem culpa sua }\end{array}$ \\
\hline Não estar desquitado & $\begin{array}{l}\text { Admite a separação há menos de dois anos, } \\
\text { não estar divorciado, caso de extinção do } \\
\text { vínculo matrimonial }\end{array}$ \\
\hline Preferência na inventariança & $\begin{array}{c}\text { Preferência na inventariança se convivente à } \\
\text { época da abertura da sucessão }\end{array}$ \\
\hline Cônjuge não poderia estar desquitado & $\begin{array}{c}\text { Possível a separação, não o divórcio, que } \\
\text { dissolve o vínculo conjugal }\end{array}$ \\
\hline- & $\begin{array}{l}\text { Concorrência com filhos comuns, reserva } \\
\text { legal de } 1 / 4 \text { da herança }\end{array}$ \\
\hline- & $\begin{array}{l}\text { Concorrência com filhos só do autor da } \\
\text { herança, sem reserva legal de } 1 / 4 \text { da herança }\end{array}$ \\
\hline- & $\begin{array}{c}\text { Concorrência com filhos comuns e filhos } \\
\text { apenas do autor da herança, sem reserva legal } \\
\text { de } 1 / 4 \text { da herança }\end{array}$ \\
\hline- & $\begin{array}{c}\text { Na concorrência com os pais do autor da } \\
\text { herança, recolherá } 1 / 3 \text { da herança }\end{array}$ \\
\hline- & $\begin{array}{c}\text { Na concorrência com apenas um dos } \\
\text { genitores ou com ascendentes em outro grau, } \\
\text { recolherá } 1 / 2 \text { da herança }\end{array}$ \\
\hline
\end{tabular}

Conhecer e discutir essas diferenças nos sistemas sucessórios para os cônjuges a partir dos ritmos históricos revela os arranques que a sociedade impôs ao legislador para aparelhar as famílias de forma igualitária.

\section{CONSIDERAÇÕES FINAIS}


No percurso da pesquisa, fez-se necessário o debate sobre as famílias democráticas. A família se transforma e ainda assim parece haver preferência pelo casamento. No Brasil no início do século XX, ela era fortemente hierarquizada, com viés patrimonialista e claramente patriarcal, atribuindo mais direitos aos homens do que as mulheres, investindo na prole comum como uma unidade de produção, e encerra o período conquistando direitos como organismo pulsante, rompendo paradigmas, reconhecendo na pluralidade a sua realização. Ao considerar múltiplas formações, reivindica igualdade e protagonismo aos seus atores nos novos cenários.

Se antes ela era formada apenas pelo casamento, rito exigido para a sua legitimação, as famílias informais, homoafetivas e heteroafetivas, abrem espaço para percorrer o século XXI. O direito posto, positivado nas codificações, apresenta diferenças e discrepâncias para as díspares famílias e o entendimento histórico é indispensável para compreender e acomodar a tensão entre a dinâmica social e a reposta jurídica.

A atribuição de direitos a cônjuges e companheiros vem em um crescente. A elevação da afetividade a valor jurídico, assim como o reconhecimento que o esforço comum não se revela apenas na divisão idêntica de custos e de tarefas, mas na promoção de um organismo pulsante, foram determinantes na reconstrução do sistema sucessório conjugal. Ainda há pontos a serem observados e rediscutidos, como o percentual da legítima e especialmente a discussão sobre a culpa sucessória.

A formação plural das famílias contemporâneas aponta para a atenção com a dignidade da pessoa humana na realização pessoal e coletiva. A complexidade do fenômeno familiar implica manter aberto o diálogo sucessório, identificando os fatos históricos e sociais determinantes à perspectiva jurídica. As alterações pelas quais o Direito Civil contemporâneo passa revelam a lógica social, e é esse o diálogo que se espera para a valorização dos direitos da personalidade.

\section{REFERÊNCIAS BIBLIOGRÁFICAS}

AZEVEDO, Álvaro Villaça. Curso De Direito Civil: Direito de Família - Vol. 6 - $2^{\text {a }}$ Ed. São Paulo: Saraiva Educação, 2019.

AZEVEDO, Álvaro Villaça. Curso de Direito Civil: Direito das Sucessões. - Vol. 7 - São Paulo : Saraiva Educação, 2019. 
BARBOSA, R. Obras Completas de Ruy Barbosa (1872-1874). v.1. t. 2. Rio de Janeiro: Ministério da Educação e Cultura, 1947.

CARNEIRO, Nelson. A luta pelo divórcio. Rio de Janeiro: Livraria São José. 1977.

CARVALHO, Luiz Paulo Vieira de. Direito das sucessões. 4. ed. rev., atual. e ampl. - São Paulo: Atlas, 2019.

DIAS, Maria Berenice. Manual de Direito das famílias. 11ª edição. São Paulo: Editora Revista dos Tribunais, 2016.

CAHALI, Francisco José. Direito das Sucessões. São Paulo: RT, $3^{\mathrm{a}}$ Edição, 2007, p. 189192.

FROTA, Pablo Malheiros da Cunha. O direito real de habitação e a sua possível relativização no direito sucessório brasileiro: primeiras reflexões. Revista de Direito Civil Contemporâneo 2016 RDCC VOL. 8. julho - setembro 2016.

FURTADO, Junia Ferreira. Chica da Silva e o contratador de Diamantes - O outro lado do mito. São Paulo: Companhia das Letras, 2003.

GAGliAnO, Pablo Stolze e PAMPLONA FILHO, Rodolfo. Novo Curso de Direito Civil. Direito das famílias. A família em perspectiva constitucional. 6 ed. revista, atualizada e ampliada. São Paulo: Saraiva, 2018.

HIRONAKA, Giselda Maria Fernandes. Comentários ao Código Civil. Vol. 20. Coord. Antonio Junqueira de Azevedo. São Paulo: Saraiva, 2a Edição, 2007, p. 228-229;

LÉVI-STRAUS, Claude. A família. In Homem, cultura e sociedade. Rio de Janeiro: Editora Fundo de Cultura. 1956.

LÔBO, Paulo. Direito Civil: Famílias. Vol. 5. $8^{\text {a }}$ ed. São Paulo: Saraiva, 2018

LÔBO, Paulo. Direito Civil: Sucessões. Vol. 6. $5^{\text {a }}$ ed. São Paulo: Saraiva Educação, 2019.

OLIVEN, Leonora Roizen Albek. CONCORRÊNCIA DESLEAL? A questão da quota parte do cônjuge sobrevivente nos regimes de comunhão de bens. Revista de Direito de Família e Sucessão, Maranhão, v. 3, n. 2, p. 121 - 138, Jul/Dez. 2017.

PEREIRA, Caio Mário da Silva. Instituições de Direito Civil. Volume V. Direito de família. $24^{\mathrm{a}}$ edição Rio de Janeiro: Forense, 2017.

REALE, Miguel. Visão geral do projeto de código civil. Disponível em http://www.miguelreale.com.br/artigos/vgpcc.htm Acesso 10 abr. 2020

RIZZARDO, Arnaldo. Direito das sucessões. 11. ed., rev. atual. ampl. - Rio de Janeiro: Forense, 2019. 
TARTUCE, Flávio. Direito civil, v. 5: Direito de Família. 13. ed. rev., atual. e ampl. - Rio de Janeiro: Forense, 2018.

VELOSO, Zeno. Direito sucessório dos companheiros. III Congresso Brasileiro de Direito de Família Ouro Preto - MG - Outubro de 2001. Disponível em http://www.ibdfam.org.br/_img/congressos/anais/188.pdf

\section{LEGISLAÇÃO}

BRASIL. Decreto $\mathrm{n}^{\circ} 1.144$ de 11 de setembro de 1861, disponível em https://www2.camara.leg.br/legin/fed/decret/1824-1899/decreto-1144-11-setembro-1861555517-publicacaooriginal-74767-pl.html Acesso: 10 abr. 2020.

BRASIL. Decreto No 1.839, de 31 de dezembro de 1907, Regula o deferimento da herança no $\begin{array}{lllll}\text { caso da } & \text { successão } & \text { ab } & \text { intestato. } & \text { Disponível }\end{array}$ https://www2.camara.leg.br/legin/fed/decret/1900-1909/decreto-1839-31-dezembro-1907580742-republicacao-103783-pl.html acesso 10 abr. 2020.

BRASIL. Regulamento $\mathrm{n}^{\mathrm{o}} 3.069$ de 17 de abril de 1863. Disponível em https://www2.camara.leg.br/legin/fed/decret/1824-1899/decreto-3069-17-abril-1863-555008publicacaooriginal-74026-pe.html Acesso: 10 abr. 2020.

BRASIL. Decreto n ${ }^{\circ} 318$ de 1890.

BRASIL. Decreto no 119 -A de 7 de janeiro de 1890.

BRASIL. Decreto Lei n ${ }^{\circ} 181$ de 24 de janeiro de 1890.

BRASIL. Decreto $\mathrm{n}^{\circ}$ 521, de 26 de Junho de 1890, Prohibe cerimonias religiosas matrimoniaes antes de celebrado o casamento civil, e estatue a sancção penal, processo e julgamento applicaveis aos infractores.

BRASIL. Lei $n^{\circ} 3.071$, de $1^{\circ}$ de janeiro de 1916.Institui o Código Civil.

BRASIL. Decreto-Lei no 8.207, de 22 de novembro de 1945.

BRASIL. Decreto-Lei no 9.461, de 5 de julho de 1946.

BRASIL. Lei $\mathrm{n}^{\circ} 883$, de 21 de outubro de 1949. Dispõe sôbre o reconhecimento de filhos ilegítimos. Disponível em http://www.planalto.gov.br/ccivil_03/LEIS/19301949/L0883impressao.htm Acesso 11 abr. 2020.

BRASIL. Lei $\mathrm{n}^{0}$ 4.121, de 27 de agosto de 1962. Dispõe sôbre a situação jurídica da mulher casada. 
BRASIL. Emenda constitucional n 9, de 28 de junho de 1977, Dá nova redação ao $\S 1^{\circ}$ do $\begin{array}{llllll}\text { artigo } & 175 & \text { da } & \text { Constituição } & \text { Federal. Disponível em }\end{array}$ http://www.planalto.gov.br/ccivil_03/Constituicao/Emendas/Emc_anterior1988/emc0977.htm Acesso em 14 abr. 2020.

BRASIL. Lei ${ }^{\circ} 6.515$ de 26 de dezembro de 1977. Lei do Divórcio.

BRASIL. Lei ${ }^{\circ}$ 8.971, de 29 de dezembro de 1994. Regula o direito dos companheiros a alimentos e à sucessão.

BRASIL. Lei $n^{\circ} 9.278$, de 10 de maio de 1996. Regula o $\S 3^{\circ}$ do art. 226 da Constituição Federal.

BRASIL. Lei n ${ }^{\circ}$ 10.406, de 11 de janeiro de 2002. Institui o Código Civil.

BRASIL. Código civil brasileiro no debate parlamentar : elementos históricos da elaboração da Lei $\mathrm{n}^{\circ}$ 10.406, de 2002 / organizador, José Theodoro Mascarenhas Menck [recurso eletrônico]. - Brasília : Câmara dos Deputados, Edições Câmara, 2012. v. - (Série memória e análise de leis ; n. 4). Disponível em codigo_civil_debate_v1_tomos1a4.pdf Acesso em 14 abr. 2020.

PORTUGAL. Ordenações Afonsinas. http://www.ci.uc.pt/ihti/proj/afonsinas/14p351.htm Acesso 14 abr. 2020. 